\title{
Burrowing of the fiddler crab Uca tangeri in the Ria Formosa in Portugal and its influence on sediment structure
}

\author{
Birgit Wolfrath \\ Department of Marine Botany, Institut für Meereskunde, Düsternbrooker Weg 20, W-2300 Kiel 1, Germany
}

\begin{abstract}
Burrowing activities of the only European fiddler crab, Uca tangeri, and its resulting influence on biotope in mudflats were investigated during 1989-1990 at Ria Formosa, Portugal. Individuals use the same burrow for ca $1 \mathrm{wk}$, then occupy another or dig a new one. Overall a burrow is inhabited for ca 3 mo by several individuals before it is abandoned. Vacated burrows decay within 2 to 3 wk. Burrow size and number vary with the season. Burrow density was highest in spring and early summer with ca 17 burrows $\mathrm{m}^{-2}$, and then decreased. Deepest burrows (up to $90 \mathrm{~cm}$ long) were found in winter, the shallowest (up to $40 \mathrm{~cm}$ long) in summer. Volume of the sediment moved by $U$. tangeri varied monthly between 3000 and $6000 \mathrm{~cm}^{3}$ per $\mathrm{m}^{2}$ of mudflat. Water is only found in the lower third of the burrow. Burrow water contains less oxygen and more nitrate than the surrounding water of the Ria Formosa.
\end{abstract}

\section{INTRODUCTION}

Fiddler crabs of the genus Uca (Brachyura, Ocypodidae) occur in nearly all tropic and subtropic regions of the world (Crane 1975). They inhabit salt marshes, mangrove zones, mudflats and sandy beaches. All species of Uca are semi-terrestrial: social life and feeding activity only take place at low tide; during high tide the crabs stay in their burrows, which are closed with a mud plug.

While many studies have been performed on American and Indian Uca species, little is known about the only European fiddler crab, Uca tangeri (Eydoux, 1835). Previous studies by Altevogt (1957) and Hagen (1962) dealt with courtship behaviour of an Andalusian population.

This work describes the burrowing activities of a population of Uca tangeri along the Portuguese Algarve coast over $12 \mathrm{mo}$ and the sediment displacements caused by these activities. Also, the changes in the structure and chemical composition of the sediment and the resulting influence on the biotope are discussed.

\section{MATERIAL AND METHODS}

Study site. The study site was located in the Ria Formosa along the Portuguese Algarve coast. The Ria Formosa is a system of salt marshes, mudflats and lagoons, sheltered from the Atlantic Ocean by islands and peninsulas. The length of this lagoon is ca $55 \mathrm{~km}$, maximum width $7 \mathrm{~km}$, with the largest area south of Faro and Olhão and 2 smaller areas ca $5 \mathrm{~km}$ to the west and $30 \mathrm{~km}$ to the east (Fig. 1). The water exchange during the tidal cycles is very high and varies over a wide range with the lunar phases. Because of an average water depth of less than $3.0 \mathrm{~m}, 50$ to $75 \%$ of Ria Formosa water is exchanged against coastal Atlantic water during each tidal period. Salinity is 36 to $38 \%$, water temperature varies from $12.5^{\circ} \mathrm{C}$ in winter to $25.5^{\circ} \mathrm{C}$ in summer.

Large populations of Uca tangeri occur on nearly all mudflats of the Ria Formosa. The adult crabs seem to have no natural predators, although the Ria Formosa harbours various species of birds, fish and cephalopods. $U$. tangeri needs sediment surface temperatures of at least $18^{\circ} \mathrm{C}$ to become active at the surface. Hence 


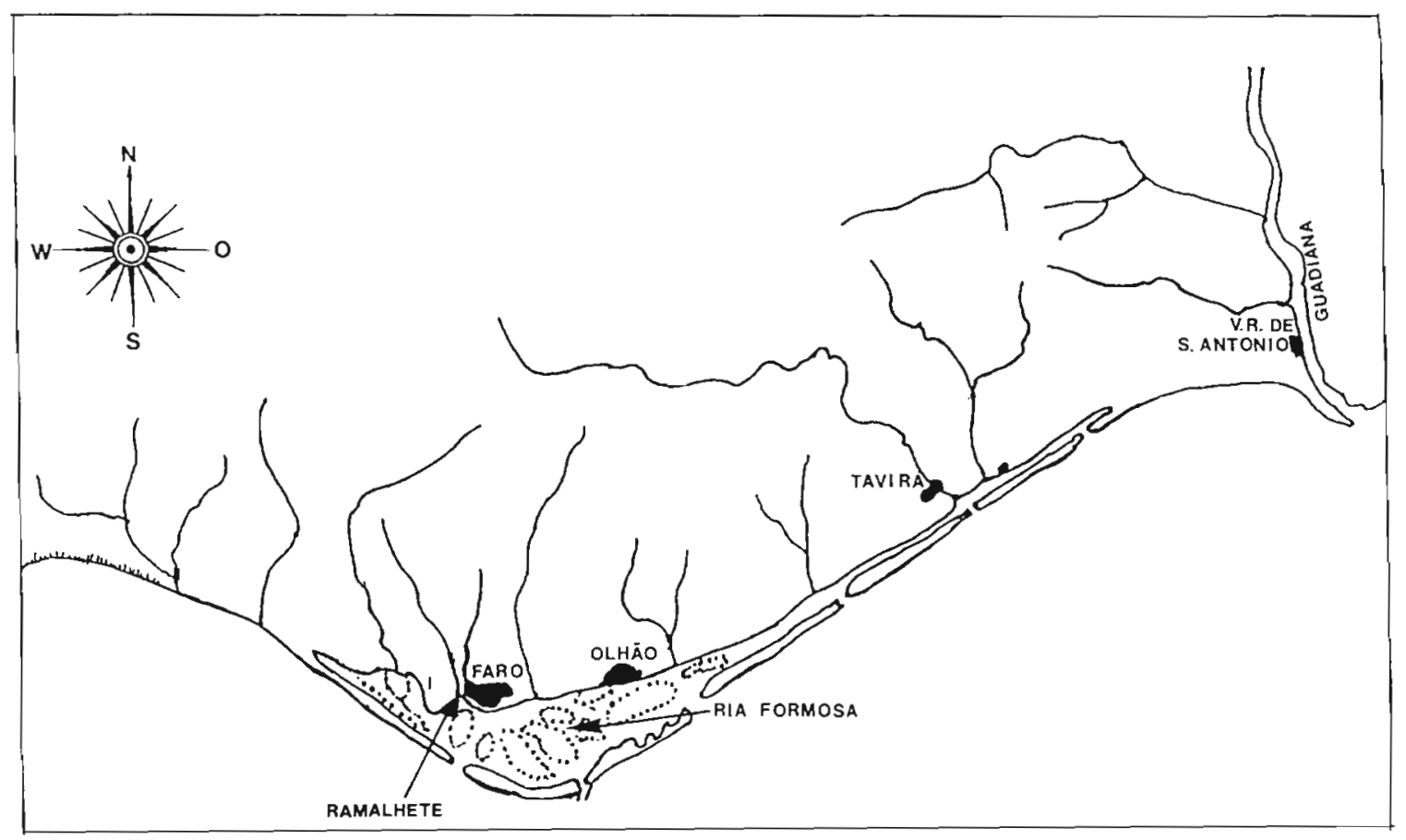

Fig. 1. Eastern Algarve coast of Portugal with the Ria Formosa and Station Ramalhete

in the Ria Formosa crabs stay in their burrows from November to March (pers. obs.).

All investigations were done conducted at Station Ramalhete (Fig. 1). This area is located far away from the tourist centers and the so called 'viveiros', zones where Portuguese fishermen harvest clams. The actual study site was a $2 \times 3 \mathrm{~m}$ section of a mudflat located near a small creek. The area rises ca $0.5 \mathrm{~m}$ above the water level at low tide and merges with a salt marsh of Arthrocnemum spp.; this is also inhabitated by $U_{C a}$ tangeri. The mudflat is exposed to air ca $1 \mathrm{~h}$ after high tide and is flooded ca $1 \mathrm{~h}$ before high tide. The height of the overlying water column varies from 0.3 to $0.8 \mathrm{~m}$. Due to the long periods, extending to 5 to $6 \mathrm{~h}$, of insolation at ebb tide, very high temperatures (up to $32^{\circ} \mathrm{C}$ in August) are reached in the upper 2 to $3 \mathrm{~cm}$ of sediment.

During the winter months from November to February, all mudflats are covered with a thick layer of long filamentous green algae. This layer begins to vanish at the end of January and is totally gone at the beginning of April.

Investigations. Observations on population and burrow dynamics took place once a week during low tide. For identification crabs were marked with waterproof, non-toxic colour on the back of their carapace; burrow entrances were identified by wire rods with small flags of coloured tape. While flags stayed intact during the entire observation time, carapace marks had to be renewed every $4 \mathrm{wk}$.
To show seasonal variations in burrow size, 12 randomly selected burrows were examined each month from August 1989 to October 1990. Burrow diameter and length were measured in order to calculate burrow volume and wall area. Samples were taken of water from the Ria Formosa and of the water which fills the lower third of the burrows (using a tube). Salinity (micro-chlorinity) and oxygen (Winkler method), nitrite and nitrate (both photometric) contents were determined and compared. Temperature readings were also taken (alcohol thermometer) for Ria Formosa water, water at the bottom of the burrow, and the surface sediment.

\section{RESULTS}

\section{General burrow structure}

Uca tangeri burrows are always constructed in the same shape. They begin with a slowly descending part ca $10 \mathrm{~cm}$ in length. After a bend of nearly $45^{\circ}$ a steeply descending part follows, ending in a chamber with a diameter of 8 to $10 \mathrm{~cm}$. Burrow length varies between 10 and $100 \mathrm{~cm}$ with season and location. Only a few burrows show a second entrance, and some have blind ending passages. Because the burrows are built into the sediment at an angle, the length of the burrow and the maximum sediment depth differ. Depending on the total length of the burrow the maximum depth is $2 \mathrm{~cm}$ 
less than the measured burrow length for short burrows (up to $25 \mathrm{~cm}$ ) and $15 \mathrm{~cm}$ less for long burrows (more than $80 \mathrm{~cm}$ ).

In general, burrows in the salt marsh of Arthrocnemum spp., located at a higher level and further away from the water, are 5 to $8 \mathrm{~cm}$ longer than burrows of the same diameter placed at a lower level of the mudflat and hence nearer the water. Therefore the sediment in the Arthrocnemum zone is influenced about 2 to $4 \mathrm{~cm}$ more deeply than that nearer the water. Burrow diameter is about $5 \mathrm{~mm}$ larger than the size of the crab digging it. The sediment removed by burrowing activities is deposited by the crabs in a range of ca $1 \mathrm{~m}$ around the burrow.

All burrows of Uca tangeri contain air in the upper two-thirds and water only in the lowest third. During high tide the burrow entrance is totally closed with mud. To test this, mud was removed from a submerged entrance: gas bubbled out. This effect is supported by the high density and hence the hardness of the burrow walls, inhibiting the seeping-in of sediment pore water. It was observed that in a burrow with a diameter of $25 \mathrm{~mm}$ the water level rose only 2 to $3 \mathrm{~mm}$ in $6 \mathrm{~h}$ of submergence.

The 2 to $3 \mathrm{~mm}$ thick sediment of the burrow walls contains only about $1 \%$ organic substance, which is less than in the surface sediment of the mudflat (about $5 \%$ ) and the Arthrocnemum zone (more than $10 \%)$

\section{Burrow number and size}

Each individual of Uca tangeri occupies its own burrow. Exceptions occur when 2 or more crabs occupy the same burrow for a short time when seeking refuge. One $U$. tangeri uses the same burrow for about 1 wk, then it takes over another burrow or digs a new one. Overall a burrow is inhabited about 3 mo (also by other crab species like Carcinus maenas or Pachygrapsus marmoratus). Burrows vacated by their owners decay and fill up with sediment within 2 or $3 \mathrm{wk}$.

The longest burrows were found in winter and spring from December 1989 to March 1990 with an average length of 64 to $68 \mathrm{~cm}$ and a maximum of $98 \mathrm{~cm}$. In summer burrows were significantly shorter with a minimum length of 31 to $32 \mathrm{~cm}$ in June and July $1990\left(p<0.001, \chi^{2}\right.$ test) and a maximum of $60 \mathrm{~cm}$. From August on, burrow length increased again (Fig. 2).

These changes were reflected in the volumes and wall areas of the burrows. Between December 1989 and March 1990 volumes of 493 to $574 \mathrm{~cm}^{3}$ were calculated, in June and July 1990 they reached only 291 to $320 \mathrm{~cm}^{3}$. Wall areas measured 621 to $690 \mathrm{~cm}^{2}$ from

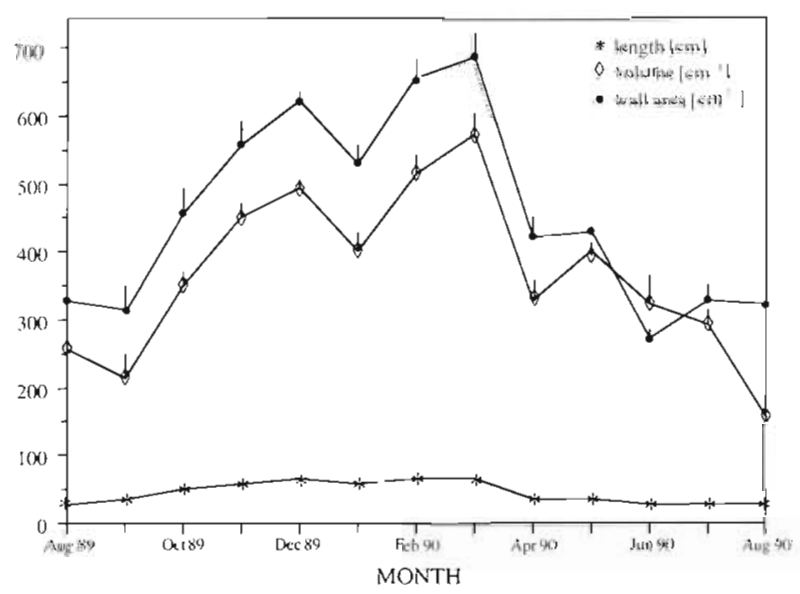

Fig. 2. Burrow length, volume and wall area from August 1989 to September 1990. Vertical bars = SE (only given in one direction to avoid confusion)

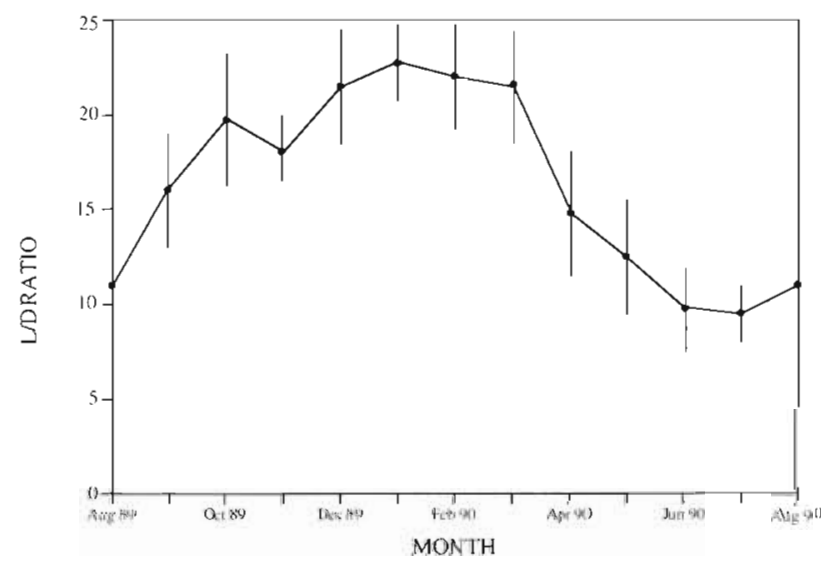

Fig. 3. Burrow length to diameter ratio $(L / D)$ from August 1989 to September 1990. Vertical bars $=\mathrm{SE}$

December 1989 to March 1990 and only 278 to $331 \mathrm{~cm}^{2}$ in June and July 1990 (Fig. 2). The average burrow diameter was 29 to $33 \mathrm{~mm}$ and hardly varied over the year.

To show annual changes in burrow size more clearly, a length to diameter ratio $(L / D)$, which reflected changes in burrow length, was calculated. Maximum $L / D$ was reached from December 1989 to March 1990 (21.5 to 22.7 ). During the following months the ratio decreased to a minimum of 9.5 in July, and then increased again (Fig. 3).

The number of burrows actually inhabited by Uca tangeri is difficult to determine. In winter, because of bad weather conditions like heavy rainfall, most of the closed burrow entrances were hardly visible. Hence no burrow counting took place from November to March. In summer, burrows recently vacated but not yet decayed resulted in incorrect numbers. 
Table 1. Uca tangeri burrow numbers, total volumes and total wall areas of burrows per $\mathrm{m}^{2}$ of mudflat from March to September 1989. Values are averages of weekly measurements. $n=$ total no. of burrows

\begin{tabular}{|lcccccc|}
\hline Month & $\begin{array}{c}\text { No. of burrows } \\
\left(\mathrm{n} \mathrm{m}^{-2}\right)\end{array}$ & $\begin{array}{c}\text { Open } \\
(\%)\end{array}$ & $\begin{array}{c}\text { Closed } \\
(\%)\end{array}$ & $\begin{array}{c}\text { Given up } \\
(\%)\end{array}$ & $\begin{array}{c}\text { Volume } \\
\left(\mathrm{cm}^{3} \mathrm{~m}^{-2}\right)\end{array}$ & $\begin{array}{c}\text { Wall area } \\
\left(\mathrm{cm}^{2} \mathrm{~m}^{-2}\right)\end{array}$ \\
\hline Mar 89 & 10 & 97 & 3 & 0 & 5740 & 6900 \\
Apr 89 & 13 & 89 & 10 & 1 & 4264 & 5499 \\
May 89 & 15 & 78 & 20 & 2 & 5985 & 6465 \\
Jun 89 & 16 & 80 & 18 & 2 & 5120 & 4448 \\
Jul 89 & 14 & 74 & 6 & 36 & 3289 & 4634 \\
Aug 89 & 13 & 61 & 9 & 45 & 3575 & 4251 \\
Sep 89 & 11 & 18 & 24 & 58 & 1518 & 1962 \\
Oct 89 & 6 & 18 & & & \\
\hline
\end{tabular}

Table 1 gives averages from weekly burrow counting from March to September 1989. From March to the end of June 1989 the number of inhabited burrows increased continously and reached the highest number in June/July with 17 burrows $\mathrm{m}^{-2}$. From the middle of July the number of vacated and decayed burrows increased and the abundance of open entrances was lower (Table 1). With the first rainfall at the end of September it became more difficult to identify closed but inhabited burrows, but the number of open burrows clearly decreased. At the beginning of November, counting was stopped because of weather conditions.

\section{Sediment displacement}

Considering number and size of burrows it is possible to calculate the amount of sediment moved by Uca tangeri over the course of a year. Depending on the season, different sediment depths are influenced.

Table 1 gives the total volume of the burrows in 1989 and hence the amounts of sediment moved by burrowing activities. The total wall area is also given. Twothirds of this area is always in contact with air and has oxic surface conditions which are clearly visible by the colour in the 1 to $2 \mathrm{~mm}$ sediment layer.

Calculations of sediment excavation included new burrows and time of burrow maintenance. The amount of sediment excavated by burrowing varied throughout the year. Largest sediment displacements took place in spring, smallest in late autumn: in March fiddler crabs excavated ca $5700 \mathrm{~cm}^{3}$ of sediment in an area of $1 \mathrm{~m}^{2}$, in October only ca $1500 \mathrm{~cm}^{3}$ (Table 1). These amounts of sediment transported by the burrowing activities of Uca tangeri are equal to a 3 to $6 \mathrm{~cm}$ thick sediment layer, depending on the season. The secondary surface of the burrow walls under a surface area of $10000 \mathrm{~cm}^{2}$ is also largest in March with ca 6900 $\mathrm{cm}^{2}$, which is an enhancement of about $70 \%$. Smallest secondary surface under an equal surface is established in October with ca $2000 \mathrm{~cm}^{2}$, an enhancement of about $20 \%$ (Table 1 ).

The amount of sediment transported by digging a new burrow is added to the amount transported during each low tide period for burrow maintenance. Also some sediment is moved by the regular opening and closing of the burrow entrances, but this is more horizontal than vertical. Considering all these effects the total amount of sediment transported and influenced by Uca tangeri burrowing activities is probably twice as high as the volumes shown in Table 1.

\section{Chemical conditions of burrow water}

Regarding the chemical composition of water in the burrows compared to that of Ria Formosa, 2 facts become quite obvious: the high nitrate content and the low oxygen content of the burrow water (Figs. $4 \& 5$ ). Nitrate in Ria Formosa water was found in very small and sometimes nearly immmeasurable amounts; burrow water, however, contained between $3.5 \mu \mathrm{mol} \mathrm{l}^{-1}$ in summer and $14.0 \mu \mathrm{mol} \mathrm{l}^{-1}$ in winter. For oxygen, conditions were reversed. Ria Formosa water had an oxygen content of 5 to $10 \mathrm{mg} \mathrm{l}^{-1}$, but water in the burrows of Uca tangeri was low in oxygen and sometimes anoxic, containing hydrogen sulfide (determined by smell).

Salinity of burrow water was the same as that of the Ria Formosa, so it is probably derived from the pore water of the surrounding sediment (Fig. 6).

\section{DISCUSSION}

Burrows are important for Uca tangeri in several ways, as described for other Uca species by many authors 1Crane 1975, Powers \& Cole 1976, Ringold 1979, Robertson et al. 1980). They serve as a refuge from predators, for moistening the gills during low tide 


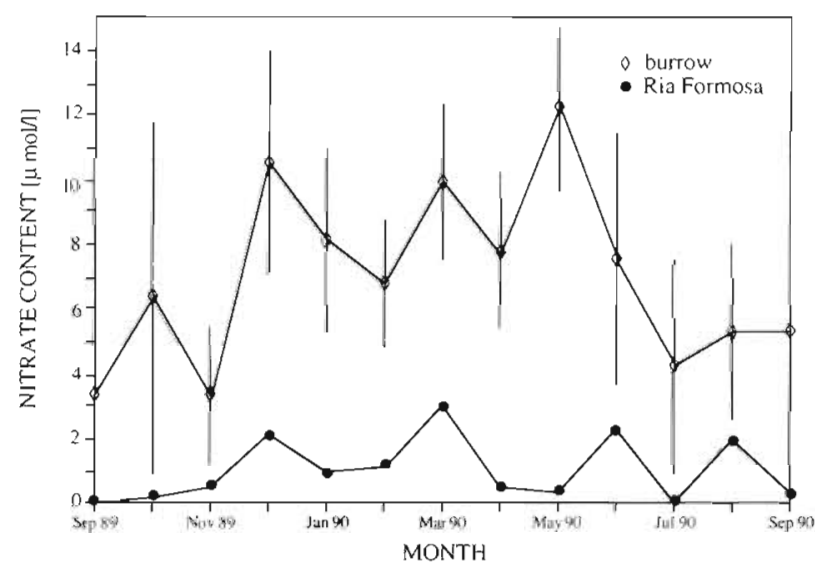

Fig, 4. Nitrate content of water inside burrows and of Ramalhete Creek from September 1989 to October 1990. Vertical bars $=\mathrm{SE}$

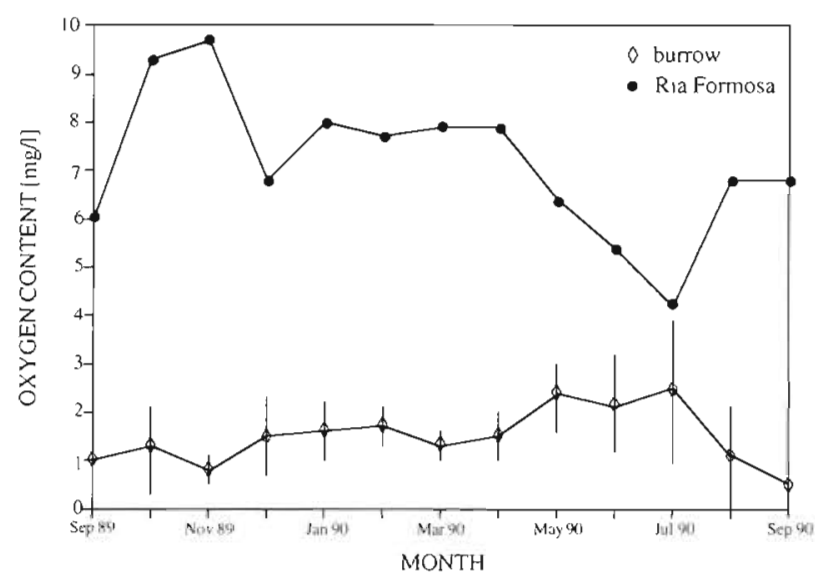

Fig. 5. Oxygen content of water inside burrows and of Ramalhete Creek from September 1989 to October 1990. Vertical bars $=\mathrm{SE}$

periods, as a place to stay in winter, and are necessary for courtship and reproduction.

Burrow sizes vary, depending on season and crab size. For interpretation of the results it must be kept in mind that Uca tangeri is not active in winter. Hence the biggest burrows are built in late autumn; the largest sediment movements must have taken place before late autumn.

To increase oxygen supply inside the burrow may be a reason for the elongation of the burrows towards winter. This would enable the crabs to stay inside the burrow for a longer time without the necessity of opening the entrance in order to exchange air. Also deeper burrows are less influenced by weather conditions like rainfall and temperature change. Although the air temperature above the mudflat fell to $4{ }^{\circ} \mathrm{C}$ in winter, the temperature at the end of the burrow was never less than $13^{\circ} \mathrm{C}$ (Fig. 7).

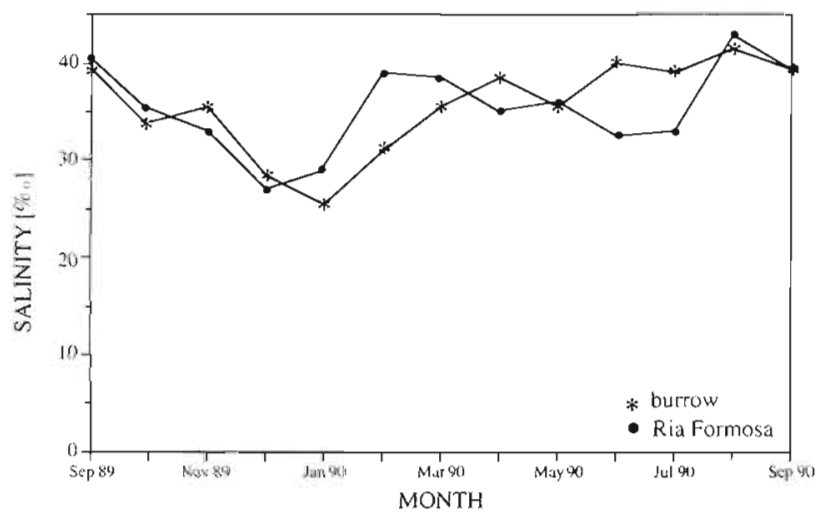

Fig. 6. Salinity of water inside burrows and of Ramalhete Creek from September 1989 to October 1990

Uca tangeri deposits the sediment removed by burrow building in a range of about $1 \mathrm{~m}$ around the burrow. This results in a sediment layer of ca $6 \mathrm{~cm} \mathrm{~m}^{-2}$ in spring and $3 \mathrm{~cm} \mathrm{~m}^{-2}$ in autumn, regardless of erosion caused by wind and water movements. This 'new' surface material has its origin in sediment depths down to about $80 \mathrm{~cm}$. Hence burrowing activities bring old material which was buried under recently deposited sediment back to the surface, so it becomes involved in the different geochemical cycles again.

Substances that were deposited deeply in the sediment become available again. Montague (1982) showed a transport of carbon and $\mathrm{CO}_{2}$ to the surface for Uca pugnax burrows and an enhanced growth of Spartina alterniflora in salt marshes at the same time. Bertness (1984, 1985) and Ringold (1979) also found this connection between the number of $U c a$ burrows and the Spartina vegetation. In the Ria Formosa this transport would mostly serve the microphytobenthos and the Arthrocnemum salt marsh community.

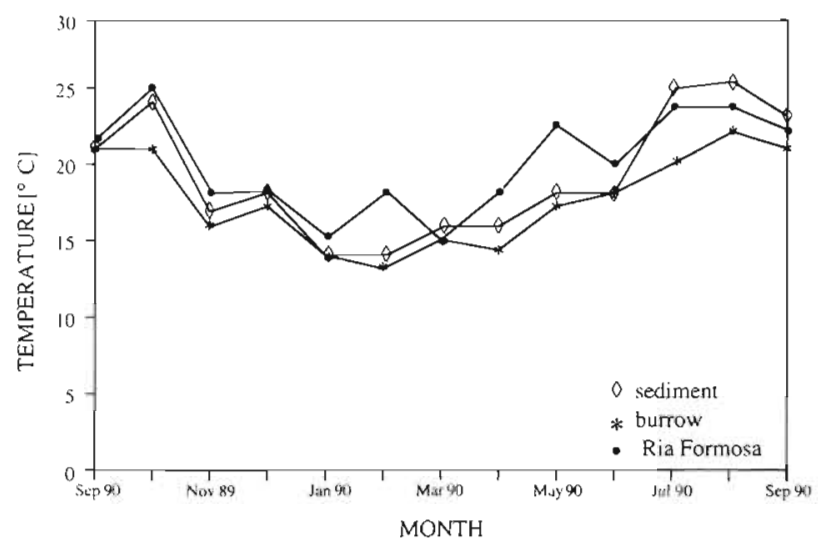

Fig. 7. Temperature of sediment surface, and water inside burrows and of Ramalhete Creek from September 1989 to October 1990 
Burrows not only increase the transport of $\mathrm{O}_{2}$ into and $\mathrm{CO}_{2}$ out of the sediment but also serve as vents to remove toxic $\mathrm{H}_{2} \mathrm{~S}$ and enhance detoxification of the sediment (Katz 1980).

Walls of Uca tangeri burrows are a secondary surface that enlarge the primary sediment surface by 30 to $70 \%$ depending on the season. Because burrows are air-filled in the upper two-thirds, sediment depths that normally are excluded from oxygen supply are aerated. From the air inside the burrow, oxygen diffuses about 0.5 to $1 \mathrm{~mm}$ into the surrounding sediment (Andersen \& Kristensen 1988), which is clearly visible by the light brown colour of the otherwise black sediment. Hence $U$. tangeri plays a big part in the oxygen transport into deeper sediment layers. This mechanism was shown previously for other macrofaunal organisms (Revsbech et al. 1980).

The influence on Ria Formosa sediment caused by Uca tangeri burrows may be greater for the mudflats than for the Arthrocnemum-zone where the plant roots already take part in the transport of $\mathrm{O}_{2}$ and $\mathrm{CO}_{2}$. This was shown by Andersen \& Kristensen (1988) for mangrove regions. There the oxic zone around the plant roots reaches about $0.5 \mathrm{~mm}$ into the surrounding sediment which is similar to the diffusion range of oxygen around $U$. tangeri burrows.

The oxygen content may be explained by the activity rhythm of $U_{c a}$ tangeri. The crab makes use of the oxygen in the air which fills the upper two-thirds of its burrow. The water in the lower third is only used to replace water lost from the gill chamber by evaporation. A renewal of air only takes place during low tides when the entrance is opened. Since the surface area for the gas exchange between air and water is very small inside the burrow, probably only part of the removed oxygen can be renewed in the water. The situation is similar in winter when $U$. tangeri stays inside the closed burrow, It is interesting that, especially during winter, the water in the burrows contains $\mathrm{H}_{2} \mathrm{~S}$. $U$. tangeri is obviously able to handle this toxic gas in a non-harmful way. An explanation may be that $U$. tangeri needs the water only for moistening the gills while the oxygen originates from the air.

The high concentration of nitrate in burrow water, especially in winter, must be explained by nitrifying processes. Nitrifying bacteria are strictly aerobic (Teal \& Kanwisher 1961, Aller \& Yingst 1978, Henriksen et al. 1980, Hylleberg \& Henriksen 1980, Katz 1980, Hüttel 1988). Unfortunately, no microbiological work was done to assess the nitrification-denitrification processes in burrow water and at the air/pore water border in the burrows. Hylleberg \& Henriksen (1980) showed that a high amount of nitrate in the burrow water leads to an increased transport of this substance into the sediment and therefore influences the envi- ronment of the burrow. There, the denitrifying processes are enhanced; this way the burrows of Uca tangeri stimulate the nitrogen-cycle in the sediment.

The results of this study document the various influences the burrows of Uca tangeri have on the biotope of the Ria Formosa. In areas inhabited by $U$. tangeri, this $c r a b$ is the only bioturbator of reasonable size.

Acknowledgements. The author thanks S. A. Gerlach and D. Barthel for their open ears to discussions on the subject and S. X. Muzavor, K. v. Bröckel, B. Lembke and A. Petersen for their help in Portugal. This study was done within the framework of a German-Portuguese research project (MFU 0563/4) and was supported by the Bundesministerium für Forschung und Technologie, the Deutscher Akademischer Ausstauschdienst and the Portuguese Ministèrio dos Negòcios Estrangeiros.

\section{LITERATURE CITED}

Aller, R. C., Yingst, J. Y. (1978), Biogeochemistry of tubedwellings: a study of the sedentary polychaete Amphitriteornata (Leidy). J. mar. Res. 36(2): 201-254

Altevogt, R. (1957). Untersuchungen zur Biologie, Ökologie und Physiologie indischer Winkerkrabben. Z. Morph. Ökol. Tiere 46: 1-110

Andersen, F. Ø., Helder, W. (1987). Comparison of oxygen microgradients, oxygen flux rates and electron transport system activity in coastal marine sediments. Mar. Ecol. Prog. Ser. 37: 259-264

Andersen, F. Ø., Kristensen, E. (1988). Oxygen microgradients in the rhizospere of the mangrove Avicennia marina. Mar. Ecol. Prog. Ser. 44: 201-204

Belchior, J. L. (1988). Faro e a Ria Formosa. Grafica Almondina, Torres Novas

Bertness, M. D. (1985). Fiddler crab regulation of Spartina alterniflora production on a New England salt marsh. Ecology 66(3): 1042-1055

Bertness, M. D., Miller, T. (1984). The distribution and dynamics of Uca pugnax (Smith) burrows in a New England salt marsh. J. exp. mar. Biol. Ecol. 83: 211-237

Broecker, W. S., Peng, T.-H. (1974). Gas exchange rates between air and sea. Tellus 26: 21-35

Crane, J. (1975). Fiddler crabs of the world. Ocypodidae: genus $U_{c a}$. Princeton Univ. Press, Princeton, New Jersey

Hagen, H.-O. v. (1962). Freilandstudien zur Sexual- und Fortpflanzungsbiologie von Uca tangeri in Andalusien. Z. Morph. Ökol. Tiere 51.611-725

Henriksen, K., Hansen, J. I., Blackburn, T H. (1980). The influence of benthic infauna on exchange rates of inorganic njtrogen between sediment and water. Ophelia, Suppl. 1: $249-256$

Hüttel, M. (1988). Zur Bedeutung der Makrofauna für die Nährsalz-Profile im. Wattsediment. Berichte aus dem Institut für Meereskunde, Nr. 182, Kiel

Hylleberg, J., Henriksen, K. (1980). The central role of bioturbation in sediment mineralization and element recycling. Ophelia, Suppl. 1: 1-16

Jargensen, B. B., Revsbech, N. P. (1985). Diffusive boundary layers and the oxygen uptake of sediment and detritus. Limnol. Oceanogr. 30(1): 111-122

Katz, L. C. (1980). Effects of burrowing by the fiddler crab, Uca pugnax (Smith). Estuar. coast. mar. Sci. 2: 233-237 
Montague, C. L. (1982). The influence of fiddler crab burrows and burrowing on metabolic processes in salt marsh sediments. In: Kennedy, V. S. (ed.) Estuarine comparisons. Academic Press, London

Powers, L. W., Cole, J F. (1976). Temperature variation in fiddler crab microhabitats. J exp. mar. Biol. Ecol. 21: 141-157

Revsbech, N. P., Sorensen, J., Blackburne, T H., Lomholt, J. H. (1980). Distribution of oxygen in marine sediments measured with microelectrodes. Limnol. Oceanogr. 25(3): 404-411

Ringold, P. (1979). Burrowing, root mat density, and the distribution of fiddler crabs in the eastern United States. J. exp. mar. Biol. Ecol. 36: 11-21

This article was submitted to the editor
Robertson, J. R., Bancroft, K., Vermeer, G., Plaisier, K. (1980). Experimental studies on the foraging behavior of the sand fiddler crab Uca pugilator (Bosc, 1802). J. exp. mar. Biol. Ecol, 44:67-83

Robertson, A. I. (1986). Leaf-burying crabs: their influence on energy flow and export from mixed mangrove forests (Rhizophora spp.) in northeastern Australia. J. exp. mar. Biol. Ecol. 102: 237-248

Teal, J. M., Kanwisher, J. (1961). Gas exchange in â Georgia salt marsh. Limnol. Oceanogr. 6: 388-399

Universidade do Algarve (1986). Parque natural da Ria Formosa. Plano de ordenamento: propostas e regulamentaçao (documento provisorio). Serviços de Documentaçao e Informaçao, Faro

Manuscript first received: March 6, 1992

Revised version accepted: July 3, 1992 